\title{
Reading Habits - An Overview
}

\author{
Ms. Kushmeeta Chettri, Dr S.K. Rout \\ Asst. Professor in Education Harkamaya College of Education Gangtok, Sikkim \\ Lecturer in Education Ravenshaw University Cuttack, Odisha
}

\begin{abstract}
Reading occupies a pivotal role in the life of a man. Reading opens the doors of the treasures of knowledge. It is an important means of introducing the child to the world that surrounds him. It is the very foundation on which the edifice of the child is to be built. Reading is one of the most important components of our language and it is an essential tool for lifelong learning for all learners. In order to face the 21st century, education has to prepare these learners to adapt to social and technological changes that are taking place at an unprecedented rate. Education under these circumstances depends largely on language competency. In this context, reading especially is a resource for continued education, for the acquisition of new knowledge and skills, for gaining information through media, especially newspapers, books, radio, television, and the computers.
\end{abstract}

Keywords- Reading habits

\section{Introduction}

"Reading is a man's bulwark against loneliness- his window on life, his unending delight. It brings yesterday and tomorrow into now". Reading provides experience through which the individual may expand his horizons of knowledge, identify, extend and intensify his interest and gains deeper understanding of himself, of other human beings and of the world. Reading has come to hold the most significant place in education as a means of communication in a highly literate society. Book is still very much part of people's lives in our modern society and in spite of the invention of the latest audio-visual materials, the book in its ordinary conventional form is still the most important means of communication ever invented.

Thus the achievement of quality basic education calls for the development of good reading habits of both young and adult learners. Reading is a key to a wealth of experience that links people in a way far beyond distance or time. Reading is important for students in general in order to cope with new knowledge in a changing world - that of the technological age. The ability to read is at the heart of self education and lifelong learning. Reading is a very important issue which is not only about enjoyment but a necessity; the basic tool of education. Reading makes way for a better understanding of one's own experiences and it can be an exciting voyage to self discovery. It is the art of interpreting printed and written words, the most effective process of conscious learning which influences the extent and accuracy of information, as well as the attitudes, morals, beliefs, judgement and action of readers (Panigrahi and Panda, 1996; Eyre, 2005).

\section{Reading Habits}

The activity of reading is regarded as a habit when it is repeatedly carried out. In measurable terms reading habits is often considered in terms of the amount of materials being read, the frequency of reading as well as the average time spent on reading (Wagner, 2002), and this habit can be cultivated (Wijesuriya, 1995).Reading, which is a long-term habit starting with the very early ages, is the prominent gateway to the knowledge room. It can be assumed as a practice that assists individuals to gain creativeness and develops their critical thinking capacities. In this sense, reading habit is an important tool for the development of personalities and mental capacities of individuals. In addition to personal and mental developments, reading is an access to social, economic and civic life (Clark and Rumbold, 2006). Moreover, all reading patterns in terms of emotional response enhance emotional satisfaction of individuals .

Reading interests often refer to the selection of subject matter or preference for a genre of literature being read (Rudman, 1957). It is therefore often equated that an individual has developed a reading habit and interests when such activity is repeatedly carried out voluntarily for leisure. Krashen (1996) believed that this habit and interests could be nurtured at an early age. There would naturally be differences in interests between individuals of different age, gender and greatly influenced by internal factors such as the home, motivation and attitude as well as external factors such as peers, schools, teachers, and the library facilities available to the individuals.

Reading habit refers to the behaviour which expresses the likeness of reading of individual types of reading and tastes of reading (Sangkaeo 1999). It is a pattern with which an individual organizes his or her 
reading. Similarly, Shen (2006), identifies reading habits, as how often, how much, and what students read. Researchers in the past decade have devoted efforts to examining learners' reading habits. With their endeavours, these researchers have discovered that reading habits are associated with students' gender, age, educational background, academic performance and professional growth. There have been attempts to categorise readers. Beers (1996) categorized 7th grade students into 3 groups. The "dormant readers" were those who liked to read and considered themselves readers but did not take the time to read regularly or update their knowledge. They were not negative to reading but gave priority to other activities such as sports, social life and school work. They would read during convenient times such as during school breaks or after completion of major projects. The second and third groups were the non-committed and unmotivated readers. Those in these two groups have negative attitude towards reading and did not like to read. The non-committed readers were open to suggestion of reading in the future and have positive attitudes towards other readers. The unmotivated readers were not open to the suggestion of future reading and were negative towards people who do read. In a more recent study, Bullent (2002) categorised reading levels of 108 children between the ages of 11 and 12 into four groups; the heavy readers (reading 24 or more books per year or 2 books per month); the moderate readers (reading 7-23 books per year or 1 book per month); rare readers (reading 1-6 books per month (1 book every 2 month) and the non readers. The last two groups form a big percentage of children between the ages of 9 to 10 , which indicated that the reading habits have not been well developed.

An examination of variations in reading habits from nation to nation demonstrates that the place occupied by books in the scale of values of those responsible for their promotion is of first importance: all State, community and school authorities, every teacher, parent and pedagogue must be seriously convinced of the importance of reading and books for individual, social, and cultural life if they are to work towards improvement of the situation be transmitted to students of reading in a way appropriate to their stage of development. The very few in ancient times before the discovery of printing, and even after the Age of Humanism it was accessible only to an educated elite and economic development makes continuous demands on the intellectual collaboration of a majority of people, has the question arisen, how the "right to read" for all can be made a reality of science, has thrown a new light on the significance of reading, not only with regard to the needs of society but also for the individual. The "right to read" also means the right to develop one's intellectual and spiritual capacities, the right to learn and make progress. Reading was once valued merely as a means of receiving an important message but, today reading research has defined the act of reading in itself as a multilevel mental process which contributes greatly to the development of the intellect. Great demands are made on the brain by the process of transforming graphic symbols into intellectual concepts; an infinite number of brain cells are activated during the storage process of reading.

Psychological studies have shown that improvement in the ability to read also leads to improvement in learning ability as a whole, going far beyond mere reception. Good reading is critical confrontation with the material and the ideas of the author. At a higher level and with longer texts, the comprehension of relationships, of construction or structure, and interpretation of the context, becomes more significant. If the new material is brought into relationship with already existing conceptions, critical reading is apt to develop into creative reading, a synthesis leading to completely new results. of systematic development of language and the personality.

\section{Importance of Reading Habits}

Reading is one of the three r's with which a child starts his education. In fact the success and failure of his academic life depends to a large extent upon his reading ability. Reading may be regarded as a basic skill to be acquired by every learner and hence every effort should be directed towards its development in children from early life. Studies have shown that schools and teachers do not have as big an influence on children as parents \& friends do. The people that children spend the most time with are the ones who govern their thoughts and directions in life. To be around people who propagate learning and reading is always a good thing for a child. There are many benefits to picking up such reading habits, especially when it comes to matters that pertain to the child's mental growth. Without a reading habit, a child can grow up with some difficulties, especially if in a line of work that requires reading at any level. Reyhene (1998) observed that when children read for pleasure, they involuntarily and unconsciously improve their language skills. Bignold (2003) indicated that the habit of reading improved children's reading skills. Hence, the issue of reading whether it is for learning or leisure is important since it helps broaden young people's experiences and knowledge (Green, 2002).

A good reading habit is necessary for a healthy intellectual growth and plays a very crucial role in enabling a person to achieve practical efficiency. Furthermore, an individual's interests are determined to a considerable extent by the amount he will read and the intensity with which he will pursue his reading activity. By reading books, one gets confirmation or rejection of one's own ideas, which makes one think more critically about right and wrong in the society. Reading provides people with a sense of values, which enable them 
gradually to develop the greatest of all virtues, that is the ability to understand rather than condemn. Books can also be very comforting, especially at times when one doubts one's self and one's beliefs.

Pleasure reading furthers the development of reading as life-long habit which strengthens both language skills and fluency noted that children improve their reading skill when they read for pleasure. Cunningham and Stanovich (1998) reported that reading volume both inside and outside the school has a significant impact on the development of reading speed and fluency, vocabulary, general knowledge overall verbal ability and academic achievements.

\section{Factors Influencing Reading Habits}

The reading habits of children have long been a matter of much interest to educators, parents, librarians' publishers and other stake holders. An understanding of reading habits and preferences of children would help them to take necessary measures for promoting reading among children. It is widely acknowledged that life-long habit of reading can best be inculcated and nurtured at the early stage. It is however a general observation that there is over emphasis on study reading rather than recreational or voluntary reading among children. Cheah(1998) noted that while students in Singapore will not hesitate to read school related materials, getting them to become life-long readers and read for the pleasure remains an uphill task. There are many factors that motivate reading among children. An international survey has shown that nearly half of the UK students participating in the study said that they read for relaxation while majority of the children from twelve developing countries revealed that they read for passing examinations (Books Aid International 2003). A study of young people in Britain aged between 11 and 18 years found that peer influence was the top most reason for reading books (Market \& Opinion International MORI, 2004). A survey of 431 pre kindergarten through grade eight students in the United States found that $71 \%$ of the students who perceived themselves as good readers had a positive attitude towards reading while none of the students who regarded themselves as poor readers enjoyed reading (Cosgrove, 2001).

A Malaysian study of 6th form students (Lim, 1974) found that the most important motivating factor was self or personal interests and this favourable attitude was well formulated among the girls and those in the Arts stream. In Sri Lanka, the National Library and Documentation Service Board (NLDB) carried out a survey in 2002 and found the following situations; reading habits of students was poor, the condition of the school libraries was not encouraging as book collections were old and most students read "light" materials such as magazines, novels, comic books and newspapers. Gunasekara (2002) studied reading problems in Sri Lankan secondary schools and found three major hindrances to the promotion of reading habits. These include; preference to chat and listen to the radio; insufficient reading resources in school libraries to be borrowed and preference for television viewing. Most reading was done mainly for examination purposes. A survey of 8000 children in Britain, aged 10,12 and 14 years found that children had very diverse reading. A similar survey conducted in Denmark on children, aged between nine and twelve years, noted a great deal of variations in children's reading preferences. It was found that over a span of one month, the children read a total of 1598 fictions and non-fiction books written by more than 700 authors. Among the Singapore children, adventure stories were the most popular, followed by the mystery stories( Balasundaram, 1991). In Australia primary school students liked reading action adventure as much as science fiction and fantasy (Woolcott Research, 2001) while in Britain, fantasy fiction was at the top, followed by humour, horror and thriller books (MORI, 2004). A study investigating the favourite past time activities of primary and middle school students in China reported that 'watching T.V.' was the most popular leisure activity, followed by reading books(Liu, 2000). A similar survey of primary 1 to secondary 5 students in Hong Kong found that watching TV and playing computer games were the two most preferred after school leisure activities (Education Department, 2001). Another study in Britain concluded that young people aged between 11 and 18 years were more likely to watch TV or use the internet than reading books (MORI, 2004).the literature review suggests that several factors particularly technological changes are likely to influence reading habits of children.

\section{Role of ICT in Promoting Reading Habits}

The day when students can trade their 30-pound book bags for lightweight portable reading devices no longer seems far in the future. Several companies are now marketing appliances that may be suitable for use in education and textbook publishers are cautiously converting some of their print titles into e-book formats. For several years, it has been anticipated that electronic books will gain wide spread use as an educational tool, but this has not yet actually come to fruition. It seems that, for the first time, all of the necessary elements are in place: inexpensive but highly functional portable reading devices, an increasing number of available book titles, and a technologically literate student population hungry for new media. The stage thus appears to be set for the single most widely used tool in the history of education, the printed textbook. The classroom is an obvious target for e-book implementation because students typically embrace new technologies $t$ purchase a high volume 
of expensive, cumbersome and rapidly discarded books. Few studies have yet been conducted to find the effects replacing standard textbooks with e-books would have on students' reading habits.

Information and Communication Technologies (ICTs) offer the readers different opportunities compared to their predecessors. ICTs have enabled libraries to transform themselves into digital libraries. Digital library is simply a collection of information stored in electronic format. For instance, the potentials delivered by African Digital library have demonstrated that People in African region can access information on the Web.The emergence of World Wide Web (WWW) is perhaps the greatest symbol of the shift in scholarly communication through reading (Magara, 2002:241). Electronic resources open up the possibility of searching multiple resources at a time - a feat accomplished more easily than when using the printed equivalents. Electronic resources can be printed and searches can be saved so that they can be repeated at a later date. Electronic resources are updated more often than printed tools. One main advantage - especially for distance learners or those with limited time to access the library - is the access available to them from outside the library by means of dial-up facilities. In addition, electronic resources are convenient to use as readers are able to access information from the library; from Internet cafés; from their offices; and - at times - from the comfort of their own homes at any time of the day.

The emerging role of ICT's and in particular use of e-resources is significantly imparting and dramatically changing the fabric of the reading habits of people. The world is going the digital way that is influencing the way people use and/or read library resources. For instance, the concept of electronic book (more widely known as e-book) is changing the reading habits among the readers. Internet in particular plays a crucial role in the access of information resources. Sources of information and other opportunities available via the Internet are increasing exponentially (Asemi, 2005). The steady increase in Internet use for education and research (Edwards \& Bruce, 2002) and the development of searching tools has impacted on the reading habits in an effort to search for knowledge. The library in terms of digital format consists of various electronic resources, such as electronic books, electronic journals, and electronic reports. These e-resources are available either in CD-ROM format, available online and those publications originally published in print or other formats converted into the digital format to be accessed on the Web (Asemi, 2005). Some of the web browsers include MSN, Netscape, and internet explorer and a number of search engines including Yahoo, Google, Hot Bot, MSN, Alta Vista. In addition e-resources may comprise of the entire manuscript collection, over-used printed document, printed material of great archival value, photographic collections, oral history recordings, and other scattered but useful audio-visual collections which are converted into digital format for preservation purposes.

Whelan (2004) describe the results of a Ohio survey of over 13,000 students from grades 3 to 2 who believed that their school libraries have helped them become better learners by providing them resources for their research assignments and helped them do their homework better. The students especially appreciate their library's role in IT instructions, providing information literacy skills, how to search the Internet, evaluating websites, using power points, words, excel and other software.

\section{Conclusion}

Recent research suggests habits of independent reading, or students choosing to read on their own time, are strong indicators of school and reading success. Scholars also find that recreational reading significantly decreases in the middle school years. A growing number of researchers are focusing on crucial questions relating to student motivation and reading habits in the middle school years (Krashen, 2004). These studies have found that students who achieved high scores on reading assessments, among other indicators of literacy learning, appeared to have high intrinsic motivation to read, and often chose to read on a regular basis outside of school. Krashen (2004), in his review of literature on independent reading, writes: "The relationship between reported free voluntary reading and literacy development is not large in every study, but it is remarkably consistent". Nearly every study that has examined this relationship has found a positive correlation, and it is present even when different tests, different methods of probing reading habits and different definitions of free reading are used. Given the complex relationships among independent reading habits, literacy learning, and school success, more research on independent reading practices and reading motivation during adolescence is needed.

\section{References}

[1]. Asemi, A. (2005). Information Searching Habits of Internet Users: A Case Study on the Medical Sciences University of Isfahan, Iran, Webology, Volume 2, Number 1, April, 2005

[2]. Balasunduram, S.(1991). A Survey of children's reading interest. Singapore book world,20.82-105

[3]. Bignold, H. (2003. Gender difference and reading. Journal of School Librarian, Vol.50, no.3: 122-133.

[4]. Bullent, Y. (2002). Reading and library usage habits of Turkish students in Austria. Journal of IFLA. Vol.28, no.2: 74-76.

[5]. Beers, K. (1996). No time, no interest, no way, the three voices of literacy. Journal of School Librarian, Vol.42, no.2: 30-33.

[6]. Cunningham, A.E. \& Stanovich, K.E. (1998). What reading does for the mind? American educator. 22(1): 8-15

[7]. Cheah, Y.M. (1998). Nurturing the Singapore readers. Reading, 32 (1): 33-34 
[8]. Cosgrove, M.S.(2001). Students' view on the purpose of reading from three perspectives students teachers and parents. In proceeding of the $12^{\text {th }}$ European reading conference. Ireland. Dublin

[9]. Clark \& Rudman, (1957). What we know about children's reading interests. International Reading Association Conference, New York: Scholastic Magazines: 23-25

[10]. Eyre, G. (2005).The development and practice of literacy: A voyage of discovery.: http://www.iasl-slo.org/ifla2005-eyre.doc Accessed on $02 / 08 / 06$

[11]. Green, P. (2002). Teachers intervention in children's reading. Journal of Child Hood Education, Vol.46, no.3, pp. 147-149

[12]. Gunasekara, P. Wijesiri. (2002). Education in Sri Lanka.. An Overview. Colombo: Deepani Printers: 22-24.

[13]. Krashen, D. (1996). Comic book reading, enjoyment and pleasure reading among middle school students. Journal of Reading Improvement, Vol.53, no.1: 51-54.

[14]. Lim, E. (1974). A study of reading habits and interests of 6 form students in English medium schools and their use of the school library facilities. M.Ed dissertation, Faculty of Education, University of Malaya.

[15]. Magara, E. (2002). Application of Digital Libraries and Electronic Technologies in Developing Countries: Practical experience for Uganda, Library Review, 51(5): 241-255

[16]. Panigrahi, C. \& Panda, K.C. (1996). Reading interests and information sources of school going children: A case study of two English medium schools of Rourkela, India. Malaysia. Journal of Library and Information Science 1 (1), pp. 57- 65.

[17]. Reyene, K. (1998). Persistence of reading diabilities. American Educational Research, Vol.28, no.4: 875-882

[18]. Sangkaeo, S. (1999). Reading habit promotion in Asean libraries. 65th IFLA Council and General Conference, Bangkok, Thailand, August 20-August 28, 1999. http://www.ifla.org/IV/ifla65/papers/091-114e.htm

[19]. Shen. L. (2006). Computer Technology and College Students' Reading Habits. Chia-nan annual bulletin, 32, pp. 559-572

[20]. Wagner, S. (2002). The reading habits of teams. Journal of Reading Today, Vol.46: 3-4.

[21]. Wijesuriya. 1995. Research on participation \& performance in primary education. Colombo: Research Project, National Institute of Education, Sri Lanka: 16-20. 